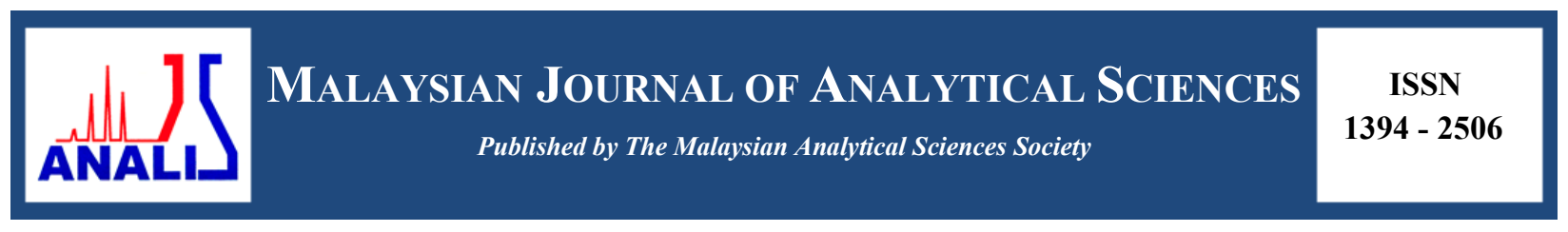

\title{
THERMAL BEHAVIORS OF OIL PALM EMPTY FRUIT BUNCH FIBER UPON EXPOSURE TO ACID-BASE AQUEOUS SOLUTIONS
}

\author{
(Perilaku Terma Serabut Tandan Kosong Sawit Selepas Rawatan Larutan Akueus Asid-Alkali) \\ Nur Syakilla Hassan ${ }^{1}$ and Khairiah Haji Badri ${ }^{1,2 *}$ \\ ${ }^{1}$ School of Chemical Sciences and Food Technology, Faculty of Science and Technology \\ ${ }^{2}$ Polymer Research Center, Faculty of Science and Technology \\ Universiti Kebangsaan Malaysia, 43600 UKM Bangi, Selangor, Malaysia \\ *Corresponding author: kaybadri@ukm.edu.my
}

Received: 10 June 2015; Accepted: 21 July 2016

\begin{abstract}
The effect of chemical treatment on the chemical composition, functional group, crystallinity and thermal stability of palm oil empty fruit bunch (EFB) fiber were investigated. Chemical treatment was conducted by treating EFB with $10 \%$ sodium hydroxide aqueous solution and $2 \%$ hydrogen peroxide aqueous solution separately. The results indicated that chemical treatment managed to affect chemical composition of the fiber. FTIR analysis proved the removing of hemicellulose and lignin during the treatment based on the peak disappearance around $1700 \mathrm{~cm}^{-1}$ and $1600 \mathrm{~cm}^{-1}$. The XRD diffractogram showed an increase in crystallinity index of the fiber especially for $\mathrm{NaOH}$ treatment. Removal the amorphous component of the fiber influences the thermal degradation of the fiber.
\end{abstract}

Keywords: empty fruit bunch, chemical treatment, thermal properties

\section{Abstrak}

Kajian ke atas serabut tandan kosong sawit (EFB) telah dijalankan untuk melihat kesan rawatan kimia terhadap komposisi serabut, kumpulan berfungsi, kehabluran dan kestabilan terma serabut. EFB telah menjalani rawatan kimia menggunakan $10 \%$ larutan akues natrium hidroksida dan 2\% larutan akues hidrogen peroksida secara berasingan. Hasil kajian menunjukkan rawatan kimia memberi kesan terhadap komposisi kimia serabut. Melalui analisis spektroskopi FTIR, penyingkiran hemiselulosa dan lignin telah berlaku semasa rawatan dijalankan. Keadaan ini dibuktikan melalui kehilangan puncak serapan sekitar $1700 \mathrm{~cm}^{-1}$ dan $1600 \mathrm{~cm}^{-1}$. Difraktogram XRD pula menunjukkan peningkatan dalam indek kehabluran bagi serabut yang menjalani rawatan $\mathrm{NaOH}$. Penyingkiran komponen amorfus didapati mempengaruhi degradasi terma serabut EFB.

Kata Kunci: tandan kosong sawit, rawatan kimia, sifat terma

\section{Introduction}

Common pretreatment for lignocellulose is to distort the lignocellulosic complex structures of the fiber. The aims of fiber pretreatment are to get rid of lignin and hemicellulose for cellulose extraction and to increase enzyme accessibility; to reduce the crystallinity of cellulose; to increase the porosity of the lignocellulosic materials and for surface modification. Fiber pretreatment can be classified into several categories; that are physical, chemical, biological or a combination of all these methods $[1,2]$.

Caustic treatment using base aqueous solutions such as sodium hydroxide $(\mathrm{NaOH})$ is one of the most used treatments studied by researchers [1]. $\mathrm{NaOH}$ helps the removal of waxes, hemicellulose, pectin and some lignin 
monomers $[3,4]$. This treatment disturbs the hydrogen bonding in cellulose and hemicellulose, breaking the ester linkages that crosslink lignin and xylan, and deprotonation of phenolic groups [5]. Treatment with high concentration of alkali may rearrange or change the crystalline structure from cellulose type I to cellulose type II [3]. Hydrogen peroxide $\left(\mathrm{H}_{2} \mathrm{O}_{2}\right)$ is an oxidizing agent in which it has the ability to decolorize the fiber by removing lignin, hemicellulose and surface impurities. $\mathrm{H}_{2} \mathrm{O}_{2}$ is always considered as a base even though it is a weak acid ( $\mathrm{pH} \sim 6.2$ ) and often used as bleaching agent in pulp and paper industry. It is often being used on lignocellulose such as oil palm empty fruit bunch fiber (EFB), kenaf, rice husk, bagasse and many others. Different treatments cause various effects to the fiber in term of degree of impurities removed and chemical composition. These also affect the thermal stability of the fiber as reported by previous researchers $[6,7,8]$.

EFB as the main feedstock in this research has been intensively studied for decades especially when Malaysia is one of the main producers of palm oil. EFB is the by-product generated after oil refining process. Approximately $400 \mathrm{~g}$ of EFB is produced from each bunch of oil palm fresh fruit and it leads to abundancy of EFB biomass [9]. At present, shredded EFB has already been used commercially since it offers several advantages in terms of availability, biodegradability and cost [10]. EFB becomes one of the important lignocelullosic materials and has extensively been used in wood and furniture industry as reinforcement of polymer-based composites. Generally EFB contain $45.0 \%$ cellulose, $32.8 \%$ hemicellulose and $20.5 \%$ lignin [11]. Cellulose is the main component of the cell wall that gives strength to plant. It consists of long carbon chains of polysaccharide. Hemicellulose is a branched polysaccharide containing sugar monomers with shorter chains and various conformations. It exists together with cellulose and lignin in the plant cell wall [12]. On the other hand, lignin is a complex polymer consists of three phenylpropane units which are cross-linked together by alkyl-aryl, alkyl-alkyl, aryl-aryl ether bonds and carbon-carbon bonds $[5,13,14]$.

The thermal behavior of the polymer can be explored using thermogravimetric analysis (TGA) and differential scanning calorimetry (DSC). TGA consist of TG curves and DTG curves. TG curve states the decomposition of polymer based on weight loss as a function of temperature while DTG curve reveals the corresponding rate of weight loss. DSC is a thermo analytical technique to determine the thermal transitions of polymer $[15,16]$. Our research goal is to investigate the influence of treatment on the thermal characteristic of EFB. Information regarding thermal degradation of natural fiber is considered important for processing temperature in applications related to development of flame retarded products, fiber-reinforced composite and many others $[17,18]$.

\section{Materials and Methods}

\section{Materials}

EFB fiber was obtained from Sri Ulu Langat Palm Oil Mill Sdn Bhd, Selangor, Malaysia. It was ground and sieved to obtain a size range of $250-315 \mu \mathrm{m}$. It was then dried in the oven at $105^{\circ} \mathrm{C}$ for 24 hours and was kept in an airtight container. Sodium hydroxide pellet $\left(\mathrm{NaOH}, \sim 99 \%\right.$ purity) and glacial acetic acid $\left(\mathrm{CH}_{3} \mathrm{COOH}, 99.8\right.$ wt.\%) were supplied by Merck (M) Sdn Bhd, Selangor, Malaysia. Hydrogen peroxide $\left(\mathrm{H}_{2} \mathrm{O}_{2}, 30-32 \%\right.$ purity) was manufactured by Friendemann Schmidt Chemical, Germany.

\section{Fiber treatment}

EFB fiber was immersed in $10 \% \mathrm{NaOH}$ aqueous solution at a ratio of 1:20 at room condition. After 48 hours, the mixture was then filtered through Büchner funnel and rinsed with diluted $\mathrm{CH}_{3} \mathrm{COOH}$ until it reached $\mathrm{pH}$ 7. The fiber was then dried in an oven at $105{ }^{\circ} \mathrm{C}$ for $24 \mathrm{~h}$ following ASTM D2016-65 (Methods of test for moisture content of wood). However, for the $\mathrm{H}_{2} \mathrm{O}_{2}$ treatment, the EFB fiber was refluxed with $2 \% \mathrm{H}_{2} \mathrm{O}_{2}$ aqueous solution at a ratio of 1:25. The treatment was conducted at $60-70{ }^{\circ} \mathrm{C}$ with continuous stirring for 3 hours. The mixture was then filtered; rinsed several times until it reached $\mathrm{pH} 7$ and dried in the oven. The treated fibers were labelled as NTF and HTF respectively and were stored in a drying chamber for further analysis.

\section{Characterization}

The physicochemical analyses carried out on the samples were determination of moisture content (TAPPI T208 om84), water solubility (TAPPI T207 om-81), and determination of ethanol-benzene extractives (TAPPI T204 cm-97), holocellulose [19], $\alpha$-cellulose (TAPPI T203 om-83) and Klason lignin content (TAPPI T222 om-83). Fourier transform infrared spectroscopy (FTIR) analysis was conducted on a spectrophotometer model Perkin Elmer 
Spectrum 400. Each spectrum was recorded in a frequency range of 4000 to $650 \mathrm{~cm}^{-1}$ using ATR-FTIR technique. The crystallinity of the sample was examined using Bruker X-ray diffractometer model D8-Advance with $\mathrm{Cu} \mathrm{K} \alpha$ radiation $(\lambda=0.15406 \mathrm{~nm})$ and the data were recorded every $0.025^{\circ}(2 \theta)$ within the range of scattering angles from $5^{\circ}$ to $60^{\circ}$. Thermogravimetric analysis (TGA) was performed using Perkin Elmer thermal analyzer. The analysis was operated under nitrogen gas atmosphere at a constant heating rate of $10{ }^{\circ} \mathrm{C} / \mathrm{min}$ heating rate. The glass transition temperatures $\left(\mathrm{T}_{\mathrm{g}}\right)$ of the samples was carried out using Mettler Toledo differential scanning calorimeter (DSC) in nitrogen gas atmosphere. The samples were first heated to $100^{\circ} \mathrm{C}$ to eliminate moisture. Then, the samples were cooled and reheated to $250^{\circ} \mathrm{C}$ at a constant heating rate of $10^{\circ} \mathrm{C} / \mathrm{min}$.

\section{Chemical composition}

\section{Results and Discussion}

Lignocellulose is composed of three main components which are cellulose, hemicellulose and lignin. The composition of these three components may differ from one fiber to another. Data of the compositional analysis conducted onto the untreated EFB (UTF), $\mathrm{NaOH}$-treated EFB (NTF) and $\mathrm{H}_{2} \mathrm{O}_{2}$-treated EFB (HTF) is presented in Table 1.

UTF contained $45.3 \%$ cellulose, $35.6 \%$ hemicellulose and $17.7 \%$ lignin. Generally, treatment with base solution was meant to remove cementing materials exist in the fiber such as lignin, hemicellulose, wax and oil [20]. Upon treatment, $\mathrm{NaOH}$ has removed a significant percentage of hemicellulose thus increasing the cellulose content for NTF compared to HTF. The percentages of cellulose, hemicellulose and lignin of HTF were $47.9 \%, 38.4 \%$ and $10.5 \%$ respectively. This indicates that hydrogen peroxide was not an efficient delignification agent for the removal of lignin and hemicellulose. On the other hand, $\mathrm{NaOH}$ worked effectively as a delignification agent where the lignin content decreased from $17.7 \%$ in the UTF to $9.0 \%$ in the NTF.

Table 1. Compositional analysis of the untreated EFB (UTF), NaOH-treated EFB (NTF) and $\mathrm{H}_{2} \mathrm{O}_{2}$-treated EFB (HTF)

\begin{tabular}{lcccc}
\hline \multirow{2}{*}{ Samples } & \multicolumn{4}{c}{ Composition percentage (\%) } \\
\cline { 2 - 5 } & Cellulose & Hemicellulose & Lignin & Others \\
\hline UTF & 45.3 & 35.6 & 17.7 & 1.4 \\
NTF & 62.4 & 19.9 & 9.0 & 8.7 \\
HTF & 47.9 & 38.4 & 10.5 & 3.2 \\
\hline
\end{tabular}

\section{Fourier transforms infrared spectroscopy}

The structural changes taking place after treatment was determined from the analysis of the FTIR spectra of UTF, NTF and HTF as shown in Figure 1. A peak observed at the region $3600-3200 \mathrm{~cm}^{-1}$ indicating hydroxyl (O-H) group in phenolic and aliphatic structures [21]. Peaks at $2850 \mathrm{~cm}^{-1}$ and $2930 \mathrm{~cm}^{-1}$ are attributed to C-H stretching vibration of methyl and methylene group [22]. After the treatment, peak at $2850 \mathrm{~cm}^{-1}$ diminished due to effect from the reduction of methyl and methylene of cellulose [23]. Differences between these spectra can be observed from the loss of absorption peak at the region $1705-1750 \mathrm{~cm}^{-1}$. These peaks corresponds to the $\mathrm{C}=\mathrm{O}$ stretching of carbonyl groups in uronic acids or acetyl in hemicellulose [24]. According to Alemdar and Sain (2008), these peaks may also indicate the ester linkage of the carboxylic group in the ferulic and $p$-coumeric acid of lignin and hemicellulose. For NTF spectra, this peak was completely disappeared while the intensity of this peak decreased for HTF spectrum. Both of these related to the removal of lignin and hemicellulose during the treatment [25]. A decrease in the intensity was observed at $1509-1609 \mathrm{~cm}^{-1}$ associated to $\mathrm{C}=\mathrm{C}$ aromatic skeletal vibrations and it was also related to delignification [26]. Differences between NTF and HTF spectra were identified based on peak intensity at specific peaks. At peak around $3300 \mathrm{~cm}^{-1}$, HTF spectrum exhibited low peak adsorption indicating that $\mathrm{H}_{2} \mathrm{O}_{2}$ treatment may cause more cellulose degradation [23]. FTIR spectra for all samples showed a peak around 898 $\mathrm{cm}^{-1}$ which is attributed to the presence of $\beta$-glycosidic linkage between glucose units in cellulose. 


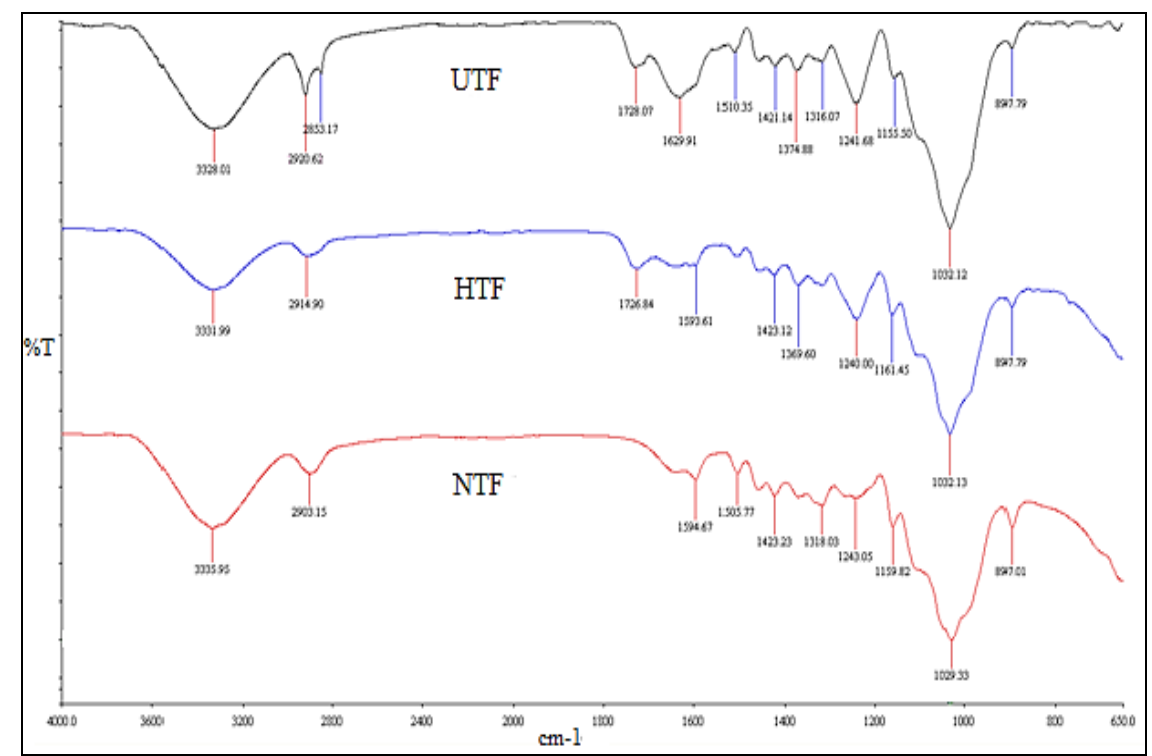

Figure 1. FTIR spectra of UTF, NTF and HTF

\section{X-ray diffraction}

X-ray diffraction (XRD) analysis was conducted onto all samples. The diffractogram are as shown in Figure 2 whereas Table 2 tabulated the crystallinity index (CrI) of the samples. Lignocellulose fiber consists of amorphous and crystalline regions that were contributed by the constituents in the fiber [27]. The crystallinity index (CrI) of the sample was calculated using the following equation 1 [28].

$$
\text { CrI, \% }=\frac{\left(\mathrm{I}_{002}-\mathrm{I}_{\mathrm{AM}}\right)}{\mathrm{I}_{002}}
$$

where $\mathrm{I}_{002}$ is the maximum intensity of the lattice diffraction at about $2 \theta \cong 22.4^{\circ}$ and $\mathrm{I}_{\mathrm{AM}}$ is the intensity attributed to the amorphous portion of sample at $2 \theta \cong 18.6^{\circ}$. From Figure 2, all samples showed similar XRD patterns with two significant peaks at $2 \theta$ position around $16.0^{\circ}$ and $22.6^{\circ}$ contributed by the crystalline regions of cellulose type I [29].

The peak around $22.6^{\circ}$ for NTF tends to be more narrow compared to UTF. This is attributed to the increase in crystallinity index of the fiber (46.2 compared to 43.0). It might be due to the removal of amorphous structure of hemicellulose and lignin during the treatment [27]. This situation is parallel to the reduction in the percentages of hemicellulose and lignin (Table 1). Upon treatment, the extracted cellulose is in the form of Cellulose Type I (main peak occurred to be unchanged). There is greater tendency for the transformation of crystalline state from cellulose I to cellulose II to happen when treated with high concentration alkaline solution [20]. However, XRD diffactrograms of HTF and UTF showed similar diffraction pattern with slight reduction in peak intensity of HTF indicating that this treatment has not made any significant changes in the crystal structure of the cellulose [29]. 


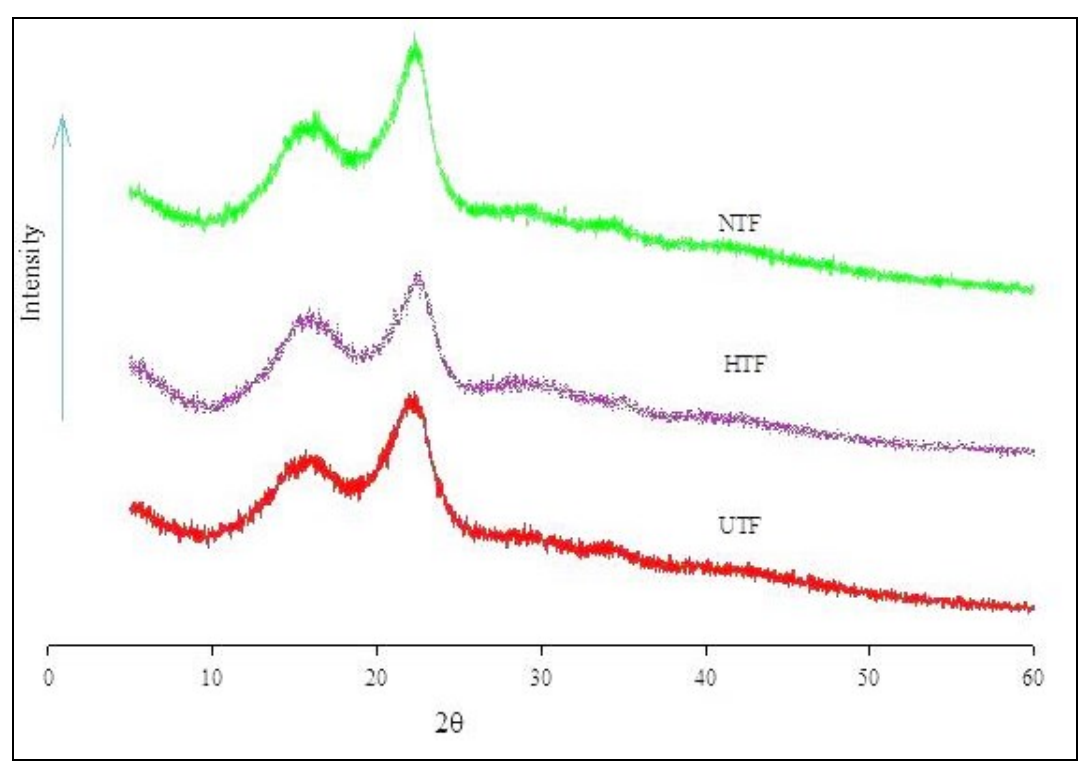

Figure 2. XRD diffactrograms of UTF, NTF and HTF

Table 2. The crystallinity index of the UTF, NTF and HTF

\begin{tabular}{llll}
\hline Sample & UTF & NTF & HTF \\
\hline Crystallinity, \% & 43.0 & 46.2 & 42.6 \\
\hline
\end{tabular}

\section{Thermogravimetric analysis}

The TG and DTG curves obtained for UTF, NTF and HTF are presented in Figure 3. The total weight loss was $70.6 \%$ for UTF, $81.8 \%$ for NTF and $89.3 \%$ HTF. The weight loss of the samples is related to the thermal degradation of hemicellulose, cellulose and lignin [7]. The DTG thermogram shows the derivative weight loss as a function of time. The peak observed around $100^{\circ} \mathrm{C}$ for all sample was connected to moisture loss.

A shoulder observed around $270{ }^{\circ} \mathrm{C}$ in the DTG peak of UTF (Figure 3(a)) was mainly related to the decomposition of extractives and hemicelluloses [30]. At this temperature range, the cleavage of glycosidic linkages of cellulose may occur as reported by Deepa et al. (2011) [7]. Major weight loss for UTF occurred around $330^{\circ} \mathrm{C}$, contributed by the degradation of cellulose. The weight loss of lignin occurs above $350{ }^{\circ} \mathrm{C}$ [7].

The disappearance of a shoulder peak around $270{ }^{\circ} \mathrm{C}$ indicated the removal of hemicellulose and extractives upon $\mathrm{NaOH}$ treatment. This was confirmed by the FTIR results with the absence of carbonyl group representing the hemicellulose [4]. The decomposition of cellulose for NTF (Figure 3 (b)) was slightly shifted to $345^{\circ} \mathrm{C}$ compared to UTF. This may be influenced by the arrangement of the molecular structure of the cellulose. Higher crystallinity means more heat is required to experience thermal degradation [4]. HTF showed two significant peaks in the DTG thermogram. The lower peak (Figure 3 (c)) at $300{ }^{\circ} \mathrm{C}$ could be associated to the trace of hemicellulose present after the treatment. A clear sharp peak around $370{ }^{\circ} \mathrm{C}$ indicated the degradation of crystalline cellulose. In the study of Brebu and Vasile, lignin thermally decomposed over a broader temperature range of $200-500{ }^{\circ} \mathrm{C}$ due to different thermal stabilities of various oxygen functional groups from its structure. Thus its scissoring occurred at different temperatures [32]. 
Nur Syakilla \& Khairiah: THERMAL BEHAVIORS OF OIL PALM EMPTY FRUIT BUNCH FIBER UPON EXPOSURE TO ACID-BASE AQUEOUS SOLUTIONS
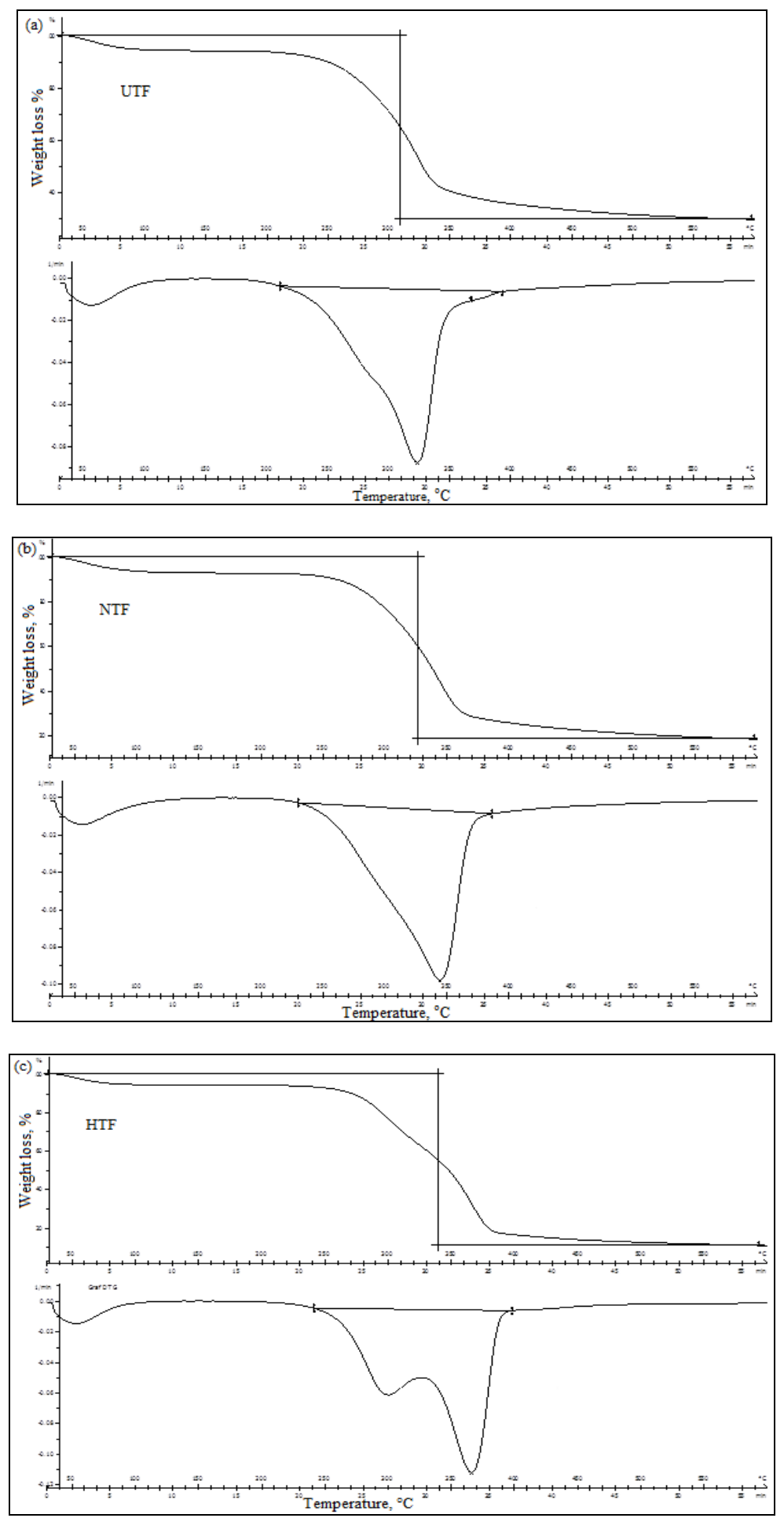

Figure 3. TG and DTG curvesof UT, NTF and HTF 


\section{Differential scanning calorimetry}

Glass transition temperature or $\mathrm{T}_{\mathrm{g}}$ is temperature at which the polymer undergoes a phase change that is from a glassy state a rubbery state. Figure 4 shows DSC thermograms of the samples. $T_{g}$ of the sample shifted to higher temperature to $186.7^{\circ} \mathrm{C}(\mathrm{NTF})$ and $185.6^{\circ} \mathrm{C}(\mathrm{HTF})$ after treatments. These treatments have greater tendency to stabilize the cellulose structure where there was an increase in cellulose crystallinity and hydrogen bonding between the closely packed cellulose chains. More energy is needed to break down the crystalline structure and to cleave the macromolecules for phase transition [31].

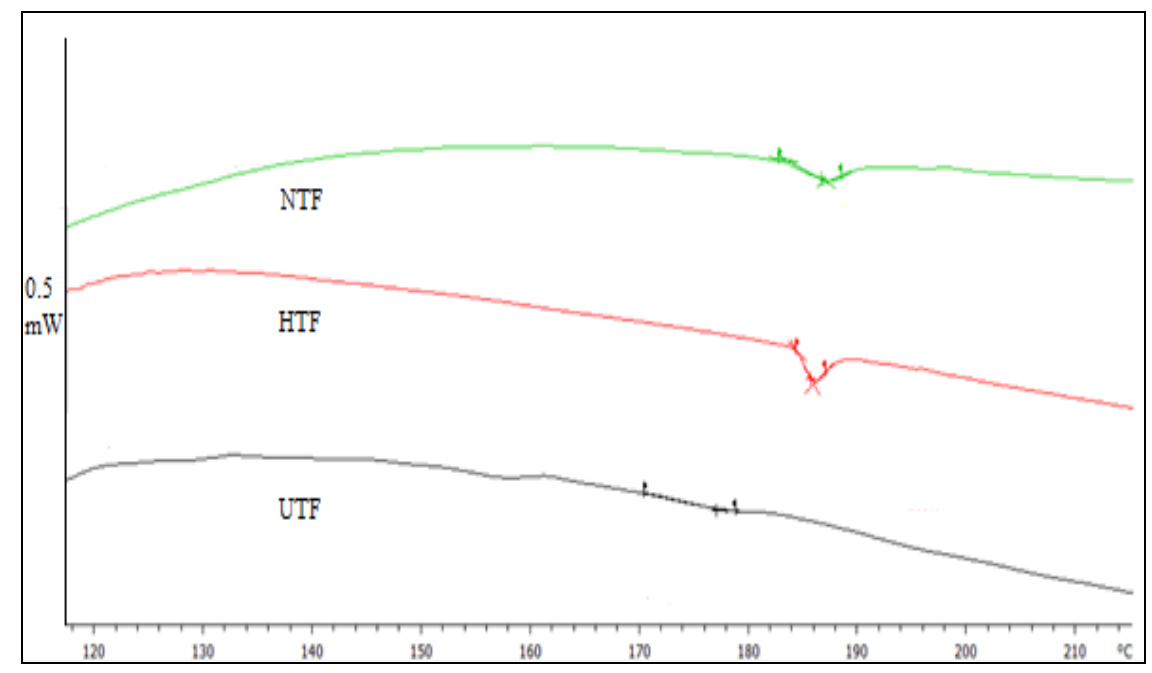

Figure 4. DSC thermograms of UTF, NTF and HTF

\section{Conclusion}

The influence of fiber treatments by acid-base approach on the chemical composition, structural and thermal stability has been investigated. Treatments caused the removal of surface impurities, lignin and hemicellulose. Alkaline treatment gave more effect in removing lignin and hemicellulose and exposing more cellulose. Thermal study reveals that thermal stability of fiber increased upon treatment. The thermal stability of the fiber was much related to the composition of the fiber.

\section{Acknowledgement}

The authors would like to thank School of Chemical Sciences and Food Technology, Faculty of Science and Technology, Universiti Kebangsaan Malaysia for providing the research facilities. A highly appreciation to the Malaysia Ministry of Higher Education for the funding of the biomass project under grant ERGS/1/2013/STG01/UKM02/2. The authors would also like to thank Malaysia Ministry of Education for the MyMaster to financially support the principal researcher.

\section{References}

1. Kumar, P., Barrett, M. D., Delwiche, J. M. and Stroeve P. (2009). Methods for pretreatment of lignocellulosic biomass for efficient hydrolysis and biofuel production. Industrial and Engineering Chemistry Research, 48 (8): $3713-3729$.

2. Harun, N. A. F., Baharuddin, A. S., Mohd Zainudin, M. H., Bahrin, E. K., Nazli Naim, M. and Zakaria, R. (2013). Cellulase production from treated oil palm empty fruit bunch degradation by locally isolated Thermobifida Fusca. Bioresourse, 8(1): 676 - 687.

3. Jayabal, S., Sathiyamurthy, S., Loganathan, K. T. and Kalyanasundaram, S. (2012). Effect of soaking time and concentration of $\mathrm{NaOH}$ solution on mechanical properties of coir-polyester composites. Bulletin of Material Science, 35(4): $567-574$. 
4. Ouajai, S. and Shanks, R. A. (2005). Composition, structure and thermal degradation of hemp cellulose after chemical treatments. Polymer Degradation and Stability, 89(2): 327 - 335.

5. Harmsen, P. F. H., Huijgen, W. J. J., Bermúdez López, L. M. and Bakke, R. R. C. (2010). Literature review of physical and chemical pretreatment processes for lignocellulosic biomass. Food and Biobased Research. 59: 1 $-49$.

6. Brígida, A. I. S., Calado, V. M. A., Gonçalves, L. R. B. and Coelho, M. A. Z. (2010). Effect of chemical treatments on properties of green coconut fiber. Carbohydrate Polymers, 79: 832 - 838 .

7. Deepa, B., Abraham, E., Cherian, B. M., Bismarck, A., Jonny, J. B., Laly, A. P., Leao, A. L., de Souza, S. F. and Kottaisamy, M. (2011). Structure, morphology and thermal characteristics of banana nano fibers obtained by steam explosion. Bioresource Technology, 102 (2): 1988 - 1997.

8. Das, H., Dutta, D., Saikia, P., Kalita, D. and Goswami, T. (2014). Novel Composite Materials from Polymeric Waste and Modified Agro-Fiber. Applied Science and Advanced Materials International, 1(1): 3 - 11.

9. Sreekala, M. S., Kumaran, M. G. and Sabu, T. (1997). Oil palm fibers: Morphology, chemical composition, surface modification, and mechanical properties. Journal of Applied Polymer Science, 66: 821 - 835.

10. Rayung, M., Ibrahim, N. A., Zainuddin, N., Saad, W. Z., Abdul Razak, N. I. and Chieng, B. W. (2014). The effect of fiber bleaching treatment on the properties of poly(lactic acid)/oil palm empty fruit bunch fiber composites. International Journal of Molecular Sciences, 15(8): 14728 - 14742.

11. Ramli, R., Stephen, S. and Jamaludin, M. A. (2002). Properties of medium density fiberboard from oil palm empty fruit bunch fiber. Journal of Oil Palm Research, 14(2): $34-40$.

12. Bulian, F. and Graystone, J. (2009). Wood Coatings: Theory and Practice Theory and Practice. Elsevier, pp 15 $-19$.

13. Mankar, S. S., Chaudhari, A. R. and Soni, I. (2012). Lignin in phenol-formaldehyde adhesives. International Journal of Knowledge Engineering, 3(1): 116 - 118.

14. Privas, E. and Navard, P. (2013). Preparation, processing and properties of lignosulfonate-flax composite boards. Carbohydrate Polymers, 93: 300 - 306.

15. Toledano, A., Serrano, L., Garcia, A., Mondragon, I. and Labidi, J. (2010). Comparative study of lignin fractionation by ultrafiltration and selective precipitation. Chemical Engineering Journal, 157 (1): 93 - 99

16. Mohamad Ibrahim, M. N. Zakaria, N. Stephen, C. S. Sulaiman, O. and Hashim, R. (2011). Chemical and thermal properties of lignins from oil palm biomass as a substitute for phenol in a phenol formaldehyde resin production. Carbohydrate Polymers, 86: $112-119$.

17. Yao, F., Wu, Q., Lei, Y., Guo, W. and Xu Y. (2008). Thermal decomposition kinetics of natural fibers: Activation energy with dynamic thermogravimetric analysis. Polymer Degradation and Stability, 93: 90 - 98.

18. Ogah, A. O., Afiukwa, J. N. and Englund, K. (2014). Characterization and comparison of thermal stability of agro waste fibers in bio-composites application. Journal of Chemical Engineering and Chemistry Research, 1(2): $84-93$.

19. Browning, B. L. (1967). Holocelluloseas perchlorite method. Methods of wood chemistry. John Wiley and Sons, pp $394-396$.

20. Abraham, E., Deepaa, B., Pothan, L. A. Jacob, M. and Thomas, S. Cvelbar U. and Anandjiwala R (2011). Extraction of nanocellulose fibrils from lignocellulosic fibers: A novel approach. Carbohydrate Polymers, $86: 1468-1475$.

21. Suradi, S. S., Yunus, R. M., Beg, M. D. H. and Yusoz, A. M. F. (2009). Influence pre-treatment on the properties of lignocellulose based biocomposite. National Conference on Postgraduate Research (NCON-PGR). Malaysia.

22. Kumar, R., Mago, G., Balan, V. and Wyman, C. E. (2009). Physical and chemical characterizations of corn stover and poplar solids resulting from leading pretreatment technologies. Bioresource Technology, 100: 3948 3962 .

23. Mohamad Remli, N. A., Md Shah, U. K., Mohamad, R. and Abd-Aziz, S. (2014). Effects of chemical and thermal pretreatments on the enzymatic saccharification of rice straw for sugars production. Bioresourse, 9(1): $510-522$.

24. Sun, X. F., Jing, Z., Fowler, P., Wu Y. and Rajaratnam, M. (2011). Structural characterization and isolation of lignin and hemicelluloses from barley straw. Industrial Crops and Products, 33: 588 - 598.

25. Alemdar, A. and Sain, M. (2008). Isolation and characterization of nanofibers from agricultural residues Wheat straw and soy hulls. Bioresource Technology, 99: 1664 - 1671. 
26. Mohamad Haafiza, M. K., Eichhorn, S. J., Hassan, A. and Jawaid, M. (2013). Isolation and characterization of microcrystalline cellulose from oil palm biomass residue. Carbohydrate Polymer, 93(2): 628 - 634 .

27. Joonobi, M., Harun, J., Shakeri, A., Misra, M. and Osman, K. (2009). Chemical composition, crystallinity and thermal degradation of bleached and unbleached Kenaf bast (Hibicus Cannabinus) pulp and nanofibers. BioResource, 4: $626-639$.

28. Segal, L., Creely, J. J., Martin, A. E. Jr. and Conrad, C. M. (1959). An empirical method for estimating the degree of crystallinity of native cellulose using the X-ray diffractometer. Textile Research Journal, 29: 786 794.

29. Poletto, M., Heitor, L., Ornaghi, J., Ademir, J. and Zattera, (2014). Native cellulose: Structure, characterization and thermal properties. Materials, 7: $6105-6119$.

30. Then, Y.Y., Ibrahin, N. A., Zainuddin, N., Chieng, B. W., Ariffin, H. and Wan Yunus, W. M. Z. (2015). Influence of alkaline peroxide treatment of fiber on mechanical properties of oil palm mesocarp fiber/poly(butylene succinate) biocomposite. Bioresources, 10(1): 1730 - 1746.

31. Haykiri-Acma, H., Yaman, S. and Kucukbayrak, S. (2010). Comparison of the thermal reactivities of isolated lignin and holocellulose during pyrolysis. Fuel Processing Technology, 91: $759-764$.

32. Brebu, M. and Vasile, C. (2010). Thermal degradation of lignin - A review. Cellulose Chemistry and Technology, 44(9): $353-363$. 